\title{
TERAHERTZES IMPULZUSOK ELŐÁLLÍTÁSA LEKÉPZÉS NÉLKÜLI MIKROSTRUKTURÁLT LÍTIUM-NIOBÁT KRISTÁLYBAN
}

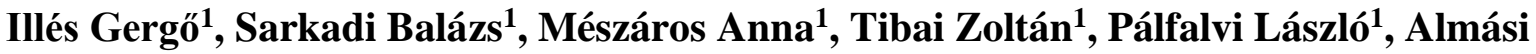 \\ Gábor $^{1,2}$, Hebling János ${ }^{1,2,3}$, Tóth György ${ }^{1,2}$ \\ ${ }^{1}$ PTE-TTK Fizikai Intézet, 7624 Pécs, Ifjúság u. 6, Magyarország \\ ${ }^{2}$ Szentágothai János Kutatóközpont, 7624 Pécs, Ifjúság u. 20, Magyarország \\ ${ }^{3}$ MTA-PTE Nagyintenzitású Terahertzes Kutatócsoport, 7624 Pécs, Ifjúság u. 6, Magyarország
}

DOI: https://doi.org/10.14232/kvantumelektronika.9.15

\section{Bevezetés}

A nagy energiájú terahertzes (THz-es) impulzusok generálására széles körben elterjedt módszer ultrarövid lézerimpulzusok optikai egyenirányítása lítium niobát (LN) kristályban döntött impulzusfrontú gerjesztést alkalmazva [1]. A nagy energia mellett nagy csúcstérerősséggel (>1 MV/cm) rendelkező THz-es impulzusok a nemlineáris spektroszkópia mellett [2] egyre ígéretesebbnek tűnnek részecskegyorsításra [3] [4], vagy akár alakformált attoszekundumos impulzusok létrehozására [5].

Utóbbi két alkalmazás esetén felvetődött az eddigieknél is nagyobb energiájú THz-es impulzusok elöállításának szükségessége. Bár a döntött impulzusfrontú technikának köszönhetően mára rutinszerüvé vált a nagy energiájú THz-es impulzusok előállítása, az energia további növelése nem látszott megoldhatónak. Ez három fő okra vezethető vissza: egyrészt a prizma alakú kristály, amiben a THz-es impulzus keletkezik, olyan THz-es nyalábot tud csak létrehozni, melynek térerősséglefutása a keresztmetszet mentén inhomogén. Másrészt a szükséges nagy impulzusfront dőlési szög jelentős szögdiszperzióval jár együtt, mely a keltő impulzus hosszának és ezzel együtt csúcsintenzitásának gyors változását eredményezi a keltés során. Harmadrészt a leképzési hibák is jelentős korlátozó tényezőként jelennek meg. Ezen korlátozó hatások enyhítése, vagy megszüntetése érdekében több megoldás is született az elmúlt években [6] [7] [8].

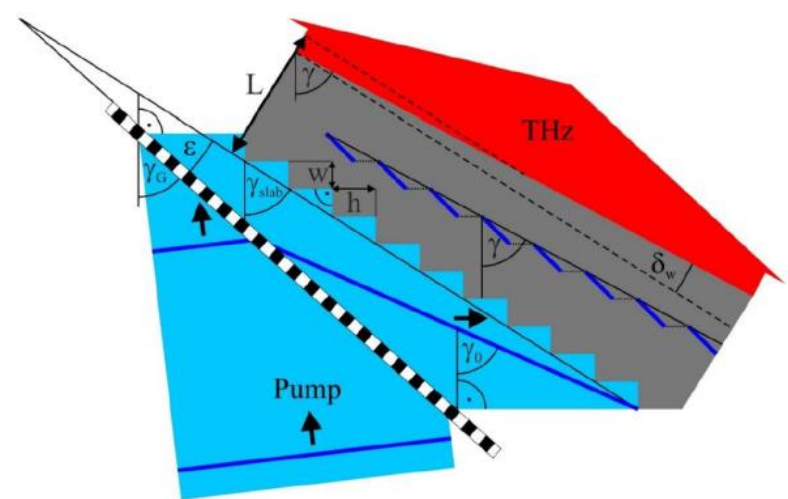

1. ábra. Leképzés nélküli NLES sematikus ábrája. A sötétkék vonalak a pumpa impulzusfrontját mutatják be három különböző időpillanatban (diffrakciós rács előtt, diffrakció során és a kristályban). [8]

Az egyik ilyen, kifejezetten rövid pumpáló impulzusok esetén jól alkalmazható megoldás a leképzés nélküli NLES (NonLinear Echelon Slab), mely elrendezés sematikus rajzát az 1. ábra mutatja be. Ebben az esetben a kristály pumpa oldali felületén tipikusan 50-70 $\mu \mathrm{m}$ széles lépcsős kristályszerkezetet, úgynevezett echelon-rácsot alakítunk ki. Ezzel elkerülhetővé válik a hagyományos döntött impulzusfrontú technikánál használt - nagy (63ํörüli) ékszög használata. Az echelon-rács alkalmazása abban a speciális esetben, amikor (a transzmissziós optikai rácson történő diffrakció eredményeként) az echelon-rács előtt az impulzusfront dőlés mértéke megegyezik a 
hatékony THz keltés érdekében a LN kristályban elérendő $63^{\circ}$ dőléssel, lehetővé teszi plán-parallel LN kristály alkalmazását. Fontos megjegyezni, hogy a hagyományos döntött impulzusfrontú elrendezés esetén a pumpáló impulzus frontjának $77^{\circ}$ dőléssel kell rendelkeznie a LN kristályba történő belépés előtt. A két szög tangensének aránya a LN csoport-törésmutatójával, 2,25-el egyezik meg.

A fenti mértékben kisebb dőlési szög 2,25² = 5,06-szor lassúbb impulzushossz-változást eredményez a LN kristályban. Az optikai rács és a LN kristály között leképzést használva, ez a speciális elrendezés megvalósítható úgy, hogy a LN kristály plán-parallel [7,9]. Azonban a leképzés kb $2 \mathrm{~cm}$-es felső határt szab a pumpáló nyaláb átméröjére. Az 1. ábra szerinti, leképzés nélküli NLES esetén leképzési hibák nyilván nem lépnek fel, de ekkor a LN-nak ékesnek kell lenni, legalábbis abban az esetben, ha a transzmissziós rácsot az 1. ábra szerinti szimmetrikus (Littrow) elrendezésben használjuk. Ekkor $\delta_{\mathrm{w}}=9,5^{\circ}$ fokos LN-t kell használni [8]. Ez az elrendezés $4 \mathrm{~cm}$ pumpáló foltátmérő alkalmazását teszi lehetôvé [8].

\section{Eredmények}

Annak érdekében, hogy a pumpáló nyaláb méretét, és azzal az elérhető THz-es energiát tovább növelhessük megvizsgáltuk azt a lehetőséget, hogy a leképzés nélküli esetben a transzmissziós rácsot nem szimmetrikus elrendezésben használjuk. Nyilvánvaló, hogy abban az esetben, ha a pumpáló nyaláb merőlegesen érkezik a rácsra, akkor a rács párhuzamos lehet a $\mathrm{LN}$ belépő felületével $\left(\varepsilon=0^{\circ}\right)$, és a LN plán-parallel lehet $\left(\delta_{\mathrm{w}}=0^{\circ}\right)$. Ennek megvalósításához $1030 \mathrm{~nm}$-es pumpálási hullámhossz esetén olyan rácsot kell használnunk, melynek karcolatsürüsége 868 vonal $/ \mathrm{mm}$. Numerikus számításokkal megmutattuk, hogy ilyen elrendezés esetén a rács diffrakciós hatásfoka mindössze $33 \%$.

Jól látszik tehát, hogy a diffrakciós veszteségek elkerülése érdekében olyan rácsot és elrendezést kell használni, mely esetben a rácsra való beesés közel van a rács adott hullámhosszhoz tartozó Littrowszögéhez. Ez ugyanakkor azt is jelenti, hogy a pumpa nem merölegesen fog a diffrakciós rácsra esni, ezért vagy a rács és az NLES pumpa felöli oldala, vagy az NLES elö-és hátoldala nem lehet párhuzamos egymással.

A következőkben, a [8]-as referenciában használt numerikus modellt felhasználva bemutatjuk, hogy Littrow-szögű elrendezés, illetve Littrow-szögtől eltérő elrendezések esetén milyen impulzusalakok és milyen hatásfokú THz-generálás érhető el. A szimulációban a pumpáló lézer központi hullámhossza $\lambda_{0}=1030 \mathrm{~nm}$, impulzushossza $\Delta t=200 \mathrm{fs}$, csúcsintenzitása: $I_{0}=70 \frac{\mathrm{GW}}{\mathrm{cm}^{2}}$.

\section{a.) Littrow-szögü elrendezés}

Az az eset, amikor a diffrakciós rács és az NLES rács felöli oldala párhuzamos és a pumpa Littrowszögben éri a rácsot, 1570 vonal/mm-es karcolatsürüségü ráccsal érhető el. Ilyenkor a diffrakciós hatásfok $87 \%$, az NLES ékszöge $\delta_{\mathrm{w}}=9,5^{\circ}$.

A 2. ábra mutatja be a létrehozható THz-es impulzus térerősséglefutását és spektrumát a THz-es nyaláb keresztmetszetének három különböző részén (a közepén, illetve attól $10 \mathrm{~mm}$-re balra és jobbra). Az ábrákon látható, hogy az elrendezés által keltett THz-es impulzus spektruma a pumpa szimmetriatengelyétől a kristály vastagabb részei felé haladva $(10 \mathrm{~mm})$ eltolódik az alacsonyabb frekvenciák irányába. Ennek oka a kristály THz-es abszorpciójának növekedése a magasabb frekvenciák esetén. A hatást a térerősséglefutásokon is megfigyelhetjük. A THz-keltés hatásfoka ebben az esetben $2,2 \%$. 

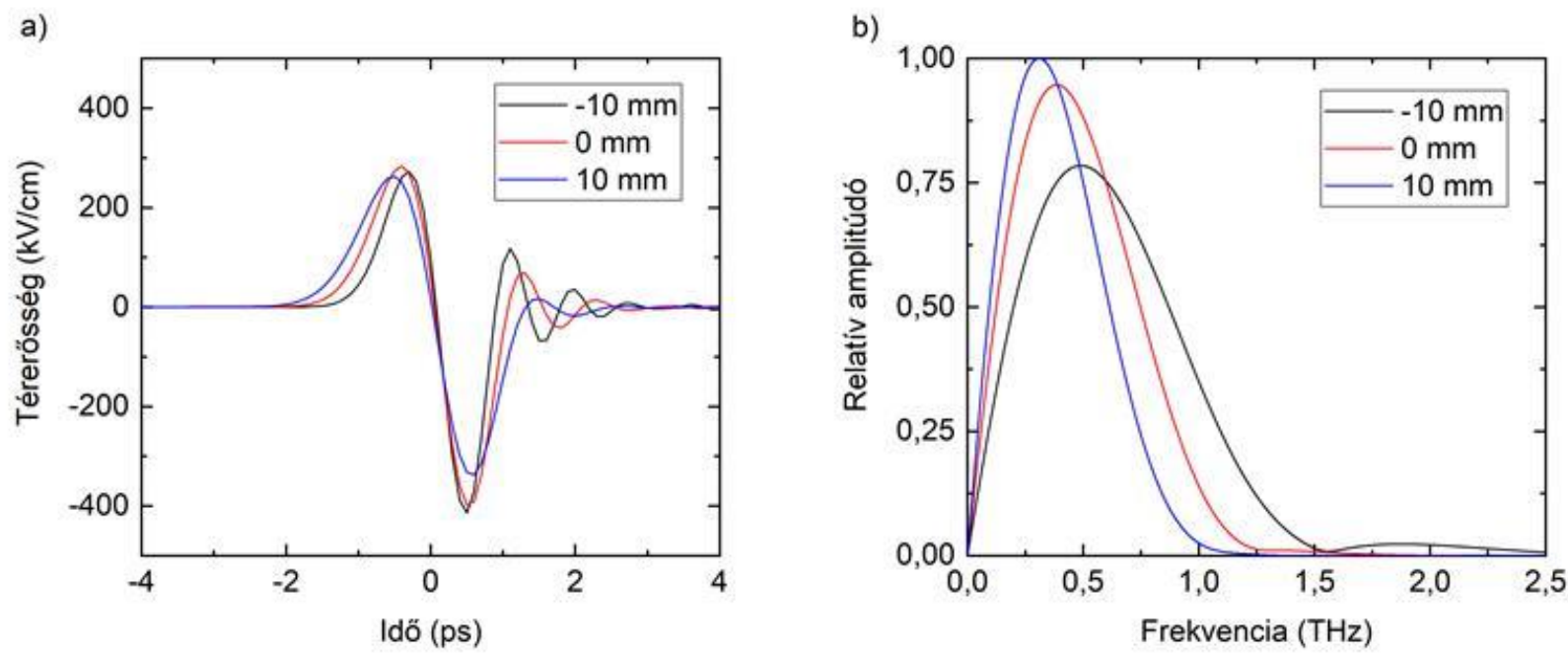

2. ábra. Littrow szögü elrendezés esetén a keletkező THz-es impulzus térerősséglefutása (a) és spektruma (b) különböző pontokban a nyaláb keresztmetszete mentén. A rács és az NLES pumpa felöli oldala párhuzamos.

Ahogy arról már szó esett Littrow-szögü beesés esetén, olyan elrendezés is megvalósítható, hogy az NLES oldalfalai párhuzamosak. Ehhez 1370 vonal/mm karcolatsűrüségü rácsra van szükség, mely 92\%-os diffrakciós hatásfokkal müködik. A rács és a kristály pumpa oldali felülete közti szög: $\varepsilon=$ 18․ A számolások eredményét a 3. ábra foglalja össze. Látható, hogy a pumpa szimmetriatengelyétől egyforma távolságokra eltérve a térerösségek és a spektrumok fedésben vannak egymással. Ez abból ered, hogy a pumpa olyan elöcsörppel rendelkezik, hogy az a fourierlimitált impulzushosszt a kristály és a nyaláb közepén érje el. Mivel nem használunk leképzést, jelen esetben a pumpa jelentős térbeli csörppel rendelkezik. Ez a csörp azonban ebben az esetben szimmetrikus a pumpa középvonalára. Az elrendezés hatásfoka 1,3\%, ami az előző eset $60 \%-\mathrm{a}$. Az eredményekböl látszik, hogy Littrow-szögü elrendezés esetén nem használható párhuzamos falú kristály, ha a keresztmetszet mentén homogén térerősséglefutást szeretnénk megkövetelni. Hogy az ékszöget mégis mérsékelni tudjuk, megvizsgáltuk, hogy milyen impulzusalakokat és keltési hatásfokot érhetünk el, amennyiben nem követeljük meg a Littrow-szögü beállítást. A továbbiakban ezeket az eredményeket mutatjuk be.

a)

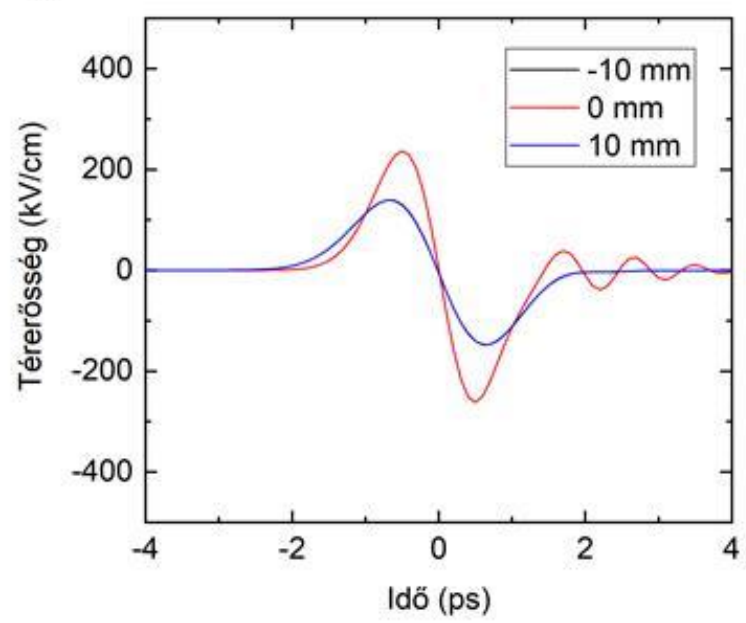

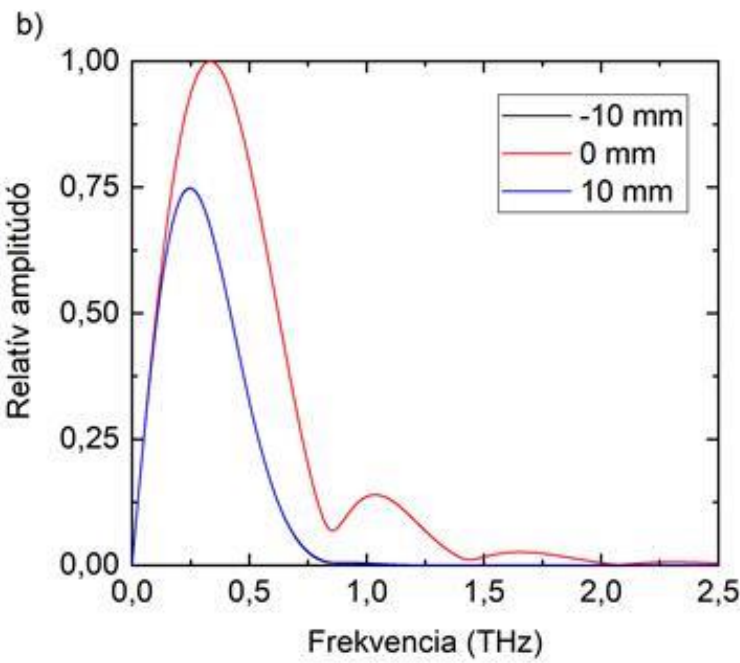

3. ábra. Littrow szögü elrendezés esetén a keletkező THz-es impulzus térerősséglefutása (a) és spektruma (b) különböző pontokban a nyaláb keresztmetszete mentén. A kristály oldalfalai párhuzamosak. 


\section{b. ) Littrow-szögtöl eltérö elrendezés}

A 4. ábrán láthatóak azok az eredmények, amikor a rács párhuzamos a kristály rács felőli felületével és a pumpa impulzus $10^{\circ}$-al (a,b ábrák), illetve $20^{\circ}$-al (c,d ábrák) tér el a Littrow-szögtől. Ezen esetekben a rács karcolatsürüsége 1360, illetve $1075 \mathrm{vonal} / \mathrm{mm}$. A pumpa rácsra való beesési szöge $34,6^{\circ}$, illetve $13,6^{\circ}$. Az NLES ékszöge $6,6^{\circ}$, valamint $2,7^{\circ}$. Az eredményeken jól látható, hogy minél párhuzamosabbak a falak, annál homogénebb $\mathrm{THz}$-es sugárzás állítható elő. A rács diffrakciós hatásfoka az első esetben $\left(10^{\circ}\right.$-os Littrowtól való eltérés esetén) $72,7 \%$, a másodikban $\left(20^{\circ}\right.$-os Littrowtól való eltérés esetén) 46,3\%. Ezen veszteségeket is figyelembe véve a THz keltés hatásfoka a rendre $1,5 \%$, és $0,8 \%$. Ugyan a $0,8 \%$ elfogadható kompromisszumnak tünik, azonban figyelemmel kell lenni arra is, hogy a rács 46,3\%-os első rendü diffrakciós hatásfoka azt is jelenti egyben, hogy a pumpa energiájának túlnyomó része a nulladik, vagy a magasabb rendekben fog megjelenni, mely nyalábok szintén bejutnak a kristályba és negatívan befolyásolhatják a THz-es impulzus alakját és a keltés hatásfokát.

a)

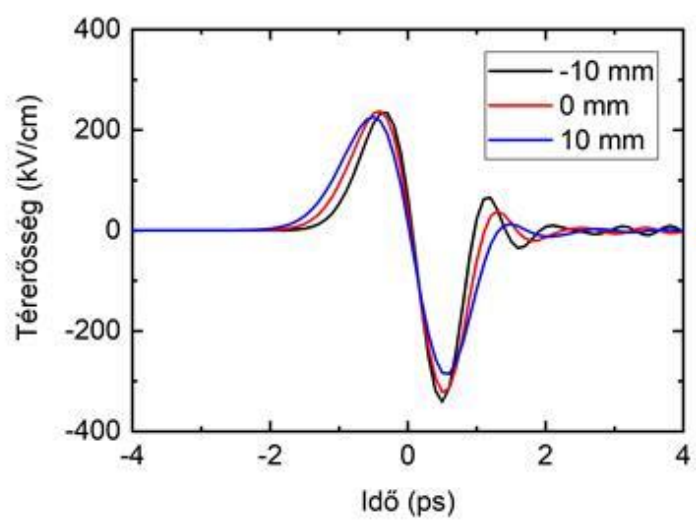

c)

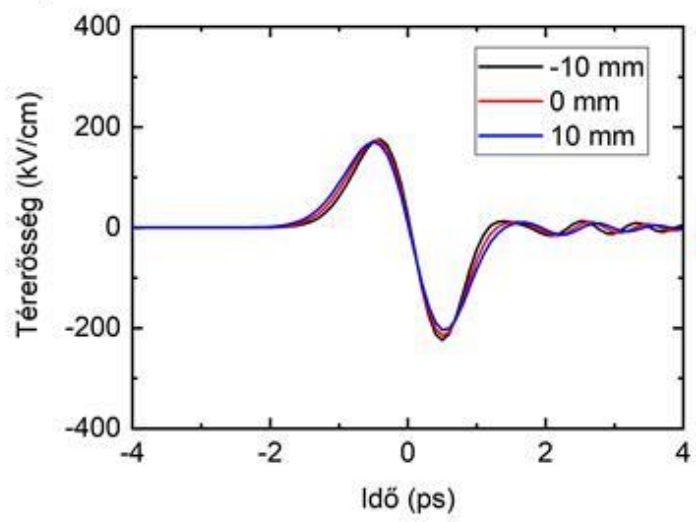

b)

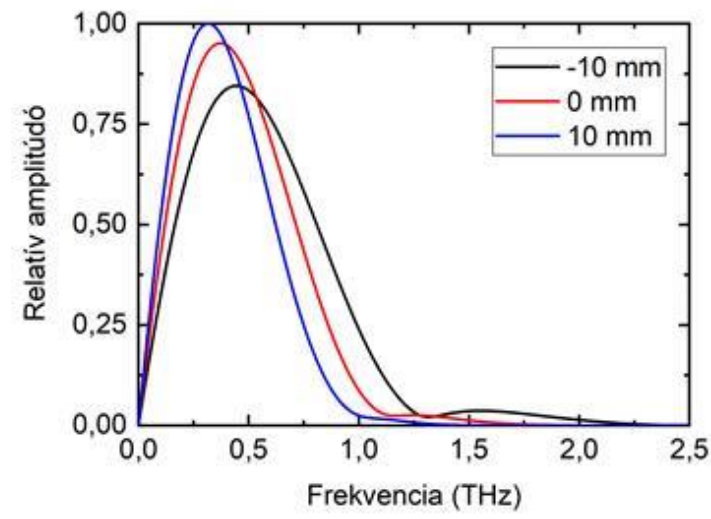

d)

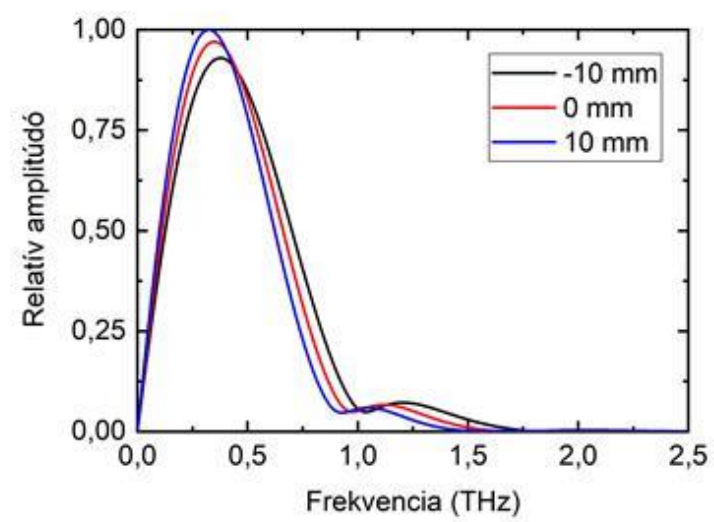

4. ábra. Littrow szögtöl $10^{\circ}$-os $(\mathrm{a}, \mathrm{b})$, illetve $20^{\circ}$-os $(\mathrm{c}, \mathrm{d})$ eltérés esetén a keletkező THz-es impulzus térerősséglefutása $(\mathrm{a}, \mathrm{c})$ és spektruma $(\mathrm{b}, \mathrm{d})$ különböző pontokban a nyaláb keresztmetszete mentén. A diffrakciós rács és a kristály rács felőli oldala párhuzamos.

Az 5. ábrán azokat az eredményeket mutatjuk be, amikor a kristály falai párhuzamosak. Ilyenkor a megfelelő elődöntés létrehozására1225 vonal/mm-es, illetve 1025 vonal/mm-es karcolatsürüségü rácsot kell használnunk a Littrow-szögtől való $10^{\circ}$-os (a és b ábra), illetve $20^{\circ}$-os (c és d ábra) eltérések esetén. Az előző esethez hasonlóan minél közelebb vagyunk a 26,5-os Littrow-szögtől való eltéréshez (amikor a pumpa merőlegesen esik a rácsra és mind a rács, mind a kristály oldalai 
párhuzamosak egymással), annál inkább homogén térerősséglefutásokat kapunk. Ezekben az esetekben a térbeli csörp mértéke egyre kisebb mértékü. A diffrakciós hatásfokok az egyes esetekben: 75,4\%, illetve 49,5\%. A THz-generálás hatásfoka 1\%, illetve 0,7\%.

a)
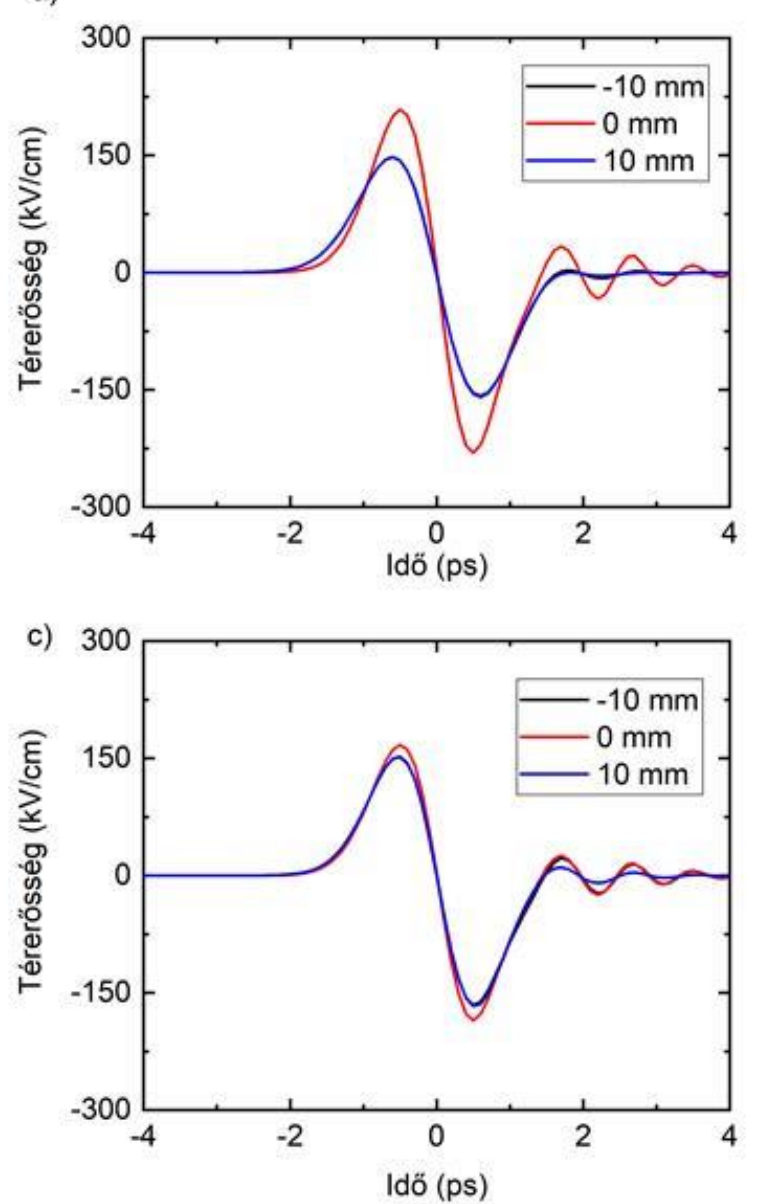

b)
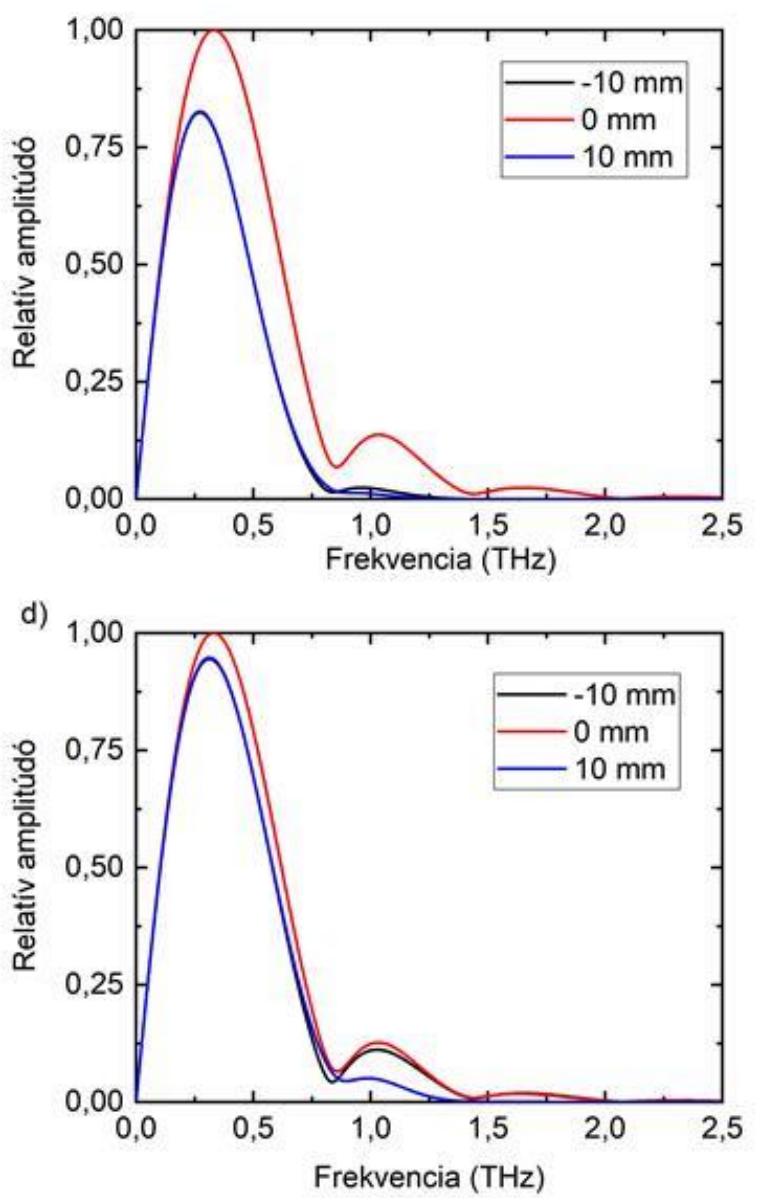

5. ábra. Littrow szögtől $10^{\circ}$-os (a, b), illetve $20^{\circ}$-os (c,d) eltérés esetén a keletkező THz-es impulzus térerösséglefutása $(\mathrm{a}, \mathrm{c})$ és spektruma (b,d ) különbözö pontokban a nyaláb keresztmetszete mentén. A kristály oldalfalai párhuzamosak.

\section{3. Összegzés}

A bemutatott elrendezések közül mind homogenitás, mind az előállított impulzusalak tekintetében azon eseteket tartottuk a legjobbaknak, ahol a rács és a kristály pumpa oldali felülete párhuzamos. Ezt az esetet emelte ki [8]-as közlemény is, melyben csak Littrow-szögű elrendezéseket vizsgáltunk. Abban az esetben az NLES ékszöge $9,4^{\circ}$ volt. A Littrow-szögtől való még tolerálható, $10^{\circ}$-os eltérés esetén ez a szög 6,6-ra csökkenthető, mely nem csak a nyaláb homogenitásán segít, hanem közel kétszeresére növeli a használható kristályméretet is. Részletes számításokkal igazoltuk, hogy ebben az esetben 182 mJ-os pumpáló energiával 2,4 mJ-os THz-es impulzusok állíthatók elő. 


\section{Köszönetnyilvánítás}

A munkát az EFOP-3.6.2-16-2017-00005 azonosító számú, Ultra-gyors fizikai folyamatok atomokban, molekulákban, nanoszerkezetekben és biológiai rendszerekben címú projekt, az 125808 számú Terahertzes részecskegyorsítás című OTKA-pályázat, valamint az ÚNKP-20-5-PTE-491 számú Bolyai+ Felsőoktatási Fiatal Oktatói, Kutatói Ösztöndíj támogatta.

\section{Irodalomjegyzék}

[1] J. Hebling, G. Almási, I. Kozma és J. Kuhl, „Velocity matching by pulse front tilting for large area THz-pulze generation," Opt. Express 10, pp. 1161-1166, 2002. https://doi.org/10.1364/OE.10.001161

[2] K.-E. Peiponen, A. Zeitler és M. Kueata-Gonokami, Terahertz Spectroscopy and Imaging, Springer Series in Optical Sciences 171, 2013, p. 171. https://doi.org/10.1007/978-3-642-29564-5

[3] E. A. Nanni, W. R. Huang, K.-H. Hong, K. Ravi, A. Fallahi, G. Moriena, R. J. D. MIller és F. X. Kärtner, „Terahertz-driven linear electron acceleration,” Nat. Commun. 6, p. 8486, 2015. https://doi.org/10.1038/ncomms9486

[4] L. Pálfalvi, J. A. Fülöp, G. Tóth és J. Hebling, „Evanescent-wave proton postaccelerator driven by intense THz pulse," Phys. Rev. ST Accel. Beams 17, p. 031301, 2014. https://doi.org/10.1103/PhysRevSTAB.17.031301

[5] G. Tóth, Z. Tibai, A. Sharma, J. A. Fülöp és J. Hebling, „Single-cycle attosecond pulses by Thomson backscattering of terahertz pulses," J. Opt. Soc. Am. B 35A103, 2018. https://doi.org/10.1364/JOSAB.35.00A103

[6] B. K. Ofori-Okai, P. Sivarajah, W. R. Huang és K. A. Nelson, „THz generation using a reflective stair-step echelon," Opt. Express 24, p. 5057, 2016. https://doi.org/10.1364/OE.24.005057

[7] L. Pálfalvi, G. Tóth, L. Tokodi, Z. Márton, J. A. Fülöp, G. Almási és J. Hebling, „Numerical investigation of a scalable setup for efficient terahertz generation using a segmetned tiltedpulse-front excitation," Opt. Express 25, pp. 29560-29573, 2017. https://doi.org/10.1364/OE.25.029560

[8] G. Tóth, L. Pálfalvi, J. A. Fülöp, G. Krizsán, N. H. Metlis, G. Almási és J. Hebling, „Numerical investigation of imaging-free terahertz generation setup using segmented tilted pulse-front excitation," Opt. Express 27, p. 7762, 2019. https://doi.org/10.1364/OE.27.007762 